\title{
Pathology of Bacterial Infection in the Liver and Kidneys of Swine
}

\author{
B. Baruah $^{1 *}$, S.M. Tamuli ${ }^{1}$ and S.M. Gogoi ${ }^{2}$ \\ ${ }^{1}$ Department of Veterinary Pathology, College of Veterinary science, Assam Agricultural \\ University (AAU), Khanapara, Guwahati-22, Assam, India \\ ${ }^{2}$ Department of Veterinary Microbiology, College of Veterinary science, Assam Agricultural \\ University (AAU), Khanapara, Guwahati-22, Assam, India \\ *Corresponding author
}

\section{A B S T R A C T}

Prevalence and pathomorphology of bacterial infection of the liver and kidneys was studied in swine population from postmortem carcasses of pigs in the

Keywords

Swine, Liver,

Kidneys, Bacteria,

Coagulative,

Centrilobular,

Infiltration, Necrosis

Article Info

Accepted:

15 July 2019

Available Online:

10 August 2019
Department of Veterinary Pathology, College of Veterinary science, Assam Agricultural University (AAU), Khanapara, Guwahati-22.A total of 21(48.8\%) liver and 9(20.9\%) kidney samples were found to be positive for the presence of bacterial infection out of 43 samples examined during the study. Bacteria isolated were mainly Streptococcus spp. (10.5\%), Staphylococcus spp. (6.97\%), Micrococcus spp. (1.16\%), E. coli (11.6\%), Klebsiella spp. (2.32\%), Pasteurella spp. (2.32\%) and some mixed bacterial infection were also recorded. Grossly, various pathological changes including congestion, haemorrhage, necrosis, abscesses were recorded in the liver and kidneys. Microscopically, focal leukocytic infiltration, centrilobular necrosis, fatty changes were recorded in the liver. Similarly various alterations such as coagulative necrosis of the renal tubules, massive haemorrhages and leukocytic infiltrations in the interstitial spaces, glomerular atrophy and sclerosis were noticed in kidneys.

\section{Introduction}

Bacterial infections are common in animals. Like other animals pigs are also susceptible to many bacterial infections. There are various bacterial diseases affecting liver and kidneys in pigs viz. leptospirosis, salmonellosis, staphylococcosis, streptococcosis, E. coli, clostridiosis, pasteurellosis etc. These bacteria produce harmful toxins and liver has to detoxifythese toxins within the body since liver has got detoxifying capacity. Liver detoxifies complex harmful bacterial toxins to simple harmless substances through a series of biochemical reactions. During this process free radicals are generated which damages hepatic cells. Due to these types of important activities liver is commonly exposed to a number of insults for which liver is the first organ to undergo various pathological changes including cellular swelling, fatty change, degeneration and necrosis etc (Vegad, 2007). 
Liver produce metabolic waste products which are filtered by the kidneys and finally excreted through the urine. Due to this type of correlation exists in between these two organs, whenever liver is subjected to any insults there is an equal possibility that the kidneys are also suffered. There are many reports on bacterial infection in pigs affecting liver and kidneys. ${ }^{[2,}$ $3,4,5,6,14,15]$

\section{Materials and Methods}

To study the prevalence and pathomorphology of bacterial infection in liver and kidneys, samples were collected from the postmortem carcasses of pigs in the Department of Veterinary Pathology, College of Veterinary science, Assam Agricultural University (AAU)), Khanapara, Guwahati-22 during the period April 2017 to March 2018.

\section{Bacteriological study}

For primary isolation Blood agar (BA) and Brain Heart Infusion agar (BHI) were used. Subsequently, presumptive colonies were subcultures onto different selective media like MacConkey Lactose agar (MLA), Manitol Salt Agar (MSA), Eosin Methylene Blue agar (EMB).To obtain isolated bacterial colonies the streak plate method was used. The samples were streaked onto $\mathrm{BA} / \mathrm{BHI}$ agar plate for primary isolation of bacteria and the inoculated plates were incubated at $37^{\circ} \mathrm{C}$ for 24-48 hours inside the incubator. Subcultures were made onto selective/ differential media for isolation particular bacteria. The bacterial isolates were identified on the basis of colony, staining, morphological and biochemical characteristics as per the method recommended by Cruickshank (1969) and Edwards et al., (1972).

\section{Coagulase test}

A suspension of the bacterial culture $(0.1 \mathrm{ml})$ was added to $0.5 \mathrm{ml}$ of rabbit plasma in a small test tube. The tube was rotated gently to mix the contents and then incubated at $37^{\circ} \mathrm{C}$, preferably in a water bath. A positive reaction was indicated by clot formation in the tube and can occurred in two to four hours. Some weakly positive strains could however require incubation at $37^{\circ} \mathrm{C}$ for upto 24 hours.

\section{Gross Pathology}

A detailed post-mortem examination of the carcasses of pigs brought to the department of pathology were carried out.

The liver and kidneys were carefully examined for any pathological changes. The observations were documented in the form of photographs and written reports.

\section{Histopathology}

For histopathological study, after proper fixation the tissue samples were processed as per the standard methods described by (Luna, 1968).

\section{Special Staining}

Wherever needed, duplicate sections were made from the affected tissue.

These sections were stained with special stain like Brown and Brenn stain for demonstration of bacteria (Fig. 2) (Brown et al., 1931).

\section{Results and Discussion}

\section{Bacteriological examination}

A total of 43 liver and 43 kidney samples were processed for isolation of different bacteria. Identification of bacteria was done based on the cultural characteristics, staining reaction, morphology and biochemical tests. The details of the cultural and staining characteristics of the bacteria isolated from the liver and kidney lesions are presented in Table 2. 
Among the isolates Gram positive cocci were dominant. The second dominant bacteria was Escherichia coli. Other species of bacteria were relatively low. The details of the bacteria isolated during the study are presented in Table 1 and Figure 1.

Staphylococcus aureus isolates produced yellow coloured round haemolytic colonies on Blood agar. Growth on Mannitol salt agar was characterized by change in the colour of the medium from red to yellow.

Gram staining showed Gram positive cocci arranged in clusters. All the isolates were tested using the Histaph identification kit (Himedia) and were also found to be coagulase positive using the tube test.

Streptococcus species produced small, pin point, circular colonies on Brain-Heart Infusion agar (BHI). No growth was observed on Mannitol salt agar. The isolates were catalase negative. Staining revealed Gram positive cocci arranged in chains or pairs.

Micrococcus species produced white, round colonies on Brain-Heart Infusion agar (BHI).The isolates were found to be susceptible to bacitracin after staining, Gram positive cocci were observed arranged in tetrads (Packs of four).

E. coli produced pink coloured lactose fermenting colonies on Mac Conkey's lactose agar and characteristics colonies with black metallic sheen on Eosin-methylene Blue Agar (EMB). Gram's staining showed Gram negative coccobacilli.

Klebsiella spp produced pink coloured, large, mucoid colonies on Mac Conkey's lactose agar and Eosin-methylene Blue Agar (EMB). Gram negative bacilli were observed under the microscope after staining. For confirmation HiIMViC test kit (Himedia) was employed.
Pasteurella spp produced smooth, round colonies on blood agar with characteristic sweetish smell. After staining, Gram negative coccobacilli exhibiting bipolar reaction were observed.

\section{Pathological Study}

A total of 14 carcasses were positive for the presence of bacterial infection out of 43 carcasses examined during the study. Bacteria isolated were mainly Streptococcus spp. (10.5\%), Staphylococcus spp. (6.97\%), Micrococcus spp. (1.16\%), E. coli (11.6\%), Klebsiella spp. (2.32\%), Pasteurella spp. $(2.32 \%)$ and some mixed bacterial infections were also recorded.

\section{Gross pathology}

A total of three cases were positive for streptococcal infection. Grossly, liver was enlarged, congested and haemorrhagic. Some patchy necrotic areas were also evident. Kidneys showed greyish white necrotic foci and congestion blood vessels.

A total of two cases which were positive for Staphylococcal infection. Grossly, micro abscesses were detected in the liver.

A total of three cases were positive for E.coli infection. Grossly, the entire viscera of carcasses showed voluminous fibrinous exudates in the pleural, pericardial and peritoneal cavities. The liver was covered with a thick pale membrane of fibrinous exudates. The kidneys were covered with thin layer of fibrin. There was marked thickening of pericardium of the heart due to deposition of fibrinous exudates and marked thickening of pleura due to deposition of fibrinous exudates.

A total of two cases were positive for Klebsieal septicaemia. Grossly, there was marked congestion of the liver. 
Table.1 Details of various bacteria isolated from liver and kidney

\begin{tabular}{|c|c|c|c|c|c|c|c|c|c|}
\hline \multirow{2}{*}{$\begin{array}{l}\text { Sl. } \\
\text { No }\end{array}$} & \multirow[t]{2}{*}{ Organs } & \multirow{2}{*}{$\begin{array}{c}\text { No of } \\
\text { samples }\end{array}$} & \multicolumn{7}{|c|}{ Number of isolates } \\
\hline & & & $\begin{array}{c}\text { Streptococcus } \\
\text { spp }\end{array}$ & $\begin{array}{c}\text { Staphylococcus } \\
\text { aureus }\end{array}$ & $\begin{array}{l}\text { Micrococcus } \\
\text { spp. }\end{array}$ & E.coli & $\begin{array}{l}\text { Klebsiella } \\
\text { spp. }\end{array}$ & $\begin{array}{l}\text { Pasteurella } \\
\text { spp. }\end{array}$ & Total \\
\hline 1 & Liver & 43 & $6(13.9 \%)$ & $5(11.6 \%)$ & - & $6(13.9 \%)$ & $2(4.65 \%)$ & $2(4.65 \%)$ & $21(48.8 \%)$ \\
\hline 2 & Kidneys & 43 & $3(6.9 \%)$ & $1(2.3 \%)$ & $1(2.3 \%)$ & $4(9.3 \%)$ & - & - & $9(20.9 \%)$ \\
\hline 3 & Total & 86 & $9(10.5 \%)$ & $6(6.97 \%)$ & $1(1.16 \%)$ & $10(10.5 \%)$ & $2(2.32 \%)$ & $2(2.32 \%)$ & $30(34.8 \%)$ \\
\hline
\end{tabular}

Table 2 Cultural colony characteristics and grams staining of the bacteria isolated from liver and lesions

\begin{tabular}{|l|l|l|}
\hline \multicolumn{1}{|c|}{ Organism } & \multicolumn{1}{|c|}{ Colony characteristics } & \multicolumn{1}{c|}{ Staining characteristics } \\
\hline Streptococcus spp. & $\begin{array}{l}\text { On BHI agar: small, pin point, circular } \\
\text { colonies } \\
\text { On MSA: No growth }\end{array}$ & $\begin{array}{l}\text { Gram positive cocci arranged in } \\
\text { chains }\end{array}$ \\
\hline $\begin{array}{l}\text { Staphylococcus } \\
\text { aureus }\end{array}$ & $\begin{array}{l}\text { On BA: Yellow, round haemolytic } \\
\text { colonies. } \\
\text { On MSA: Growth with change in colour of } \\
\text { the medium }\end{array}$ & $\begin{array}{l}\text { Gram positive cocci arranged in } \\
\text { clusters }\end{array}$ \\
\hline Micrococcus spp. & On BHI agar: white, round, colonies & $\begin{array}{l}\text { Gram positive cocci arranged as } \\
\text { tetrads }\end{array}$ \\
\hline Pasteurella spp. & $\begin{array}{l}\text { On BA: smooth, round transluscent } \\
\text { colonies } \\
\text { On MLA: No growth }\end{array}$ & $\begin{array}{l}\text { Gram negative coccobacilli } \\
\text { exhibiting bipolar staining }\end{array}$ \\
\hline E.coli & $\begin{array}{l}\text { On MLA: pink, lactose fermenting } \\
\text { colonies.On EMB agar: Colonies with } \\
\text { black metallic sheen }\end{array}$ & $\begin{array}{l}\text { Gram negative bacilli arranged } \\
\text { singly }\end{array}$ \\
\hline Klebsiella spp. & $\begin{array}{l}\text { On MLA and EMB agar: large, mucoid, } \\
\text { pink colonies }\end{array}$ & $\begin{array}{l}\text { Gram negative bacilli arranged } \\
\text { singly }\end{array}$ \\
\hline
\end{tabular}




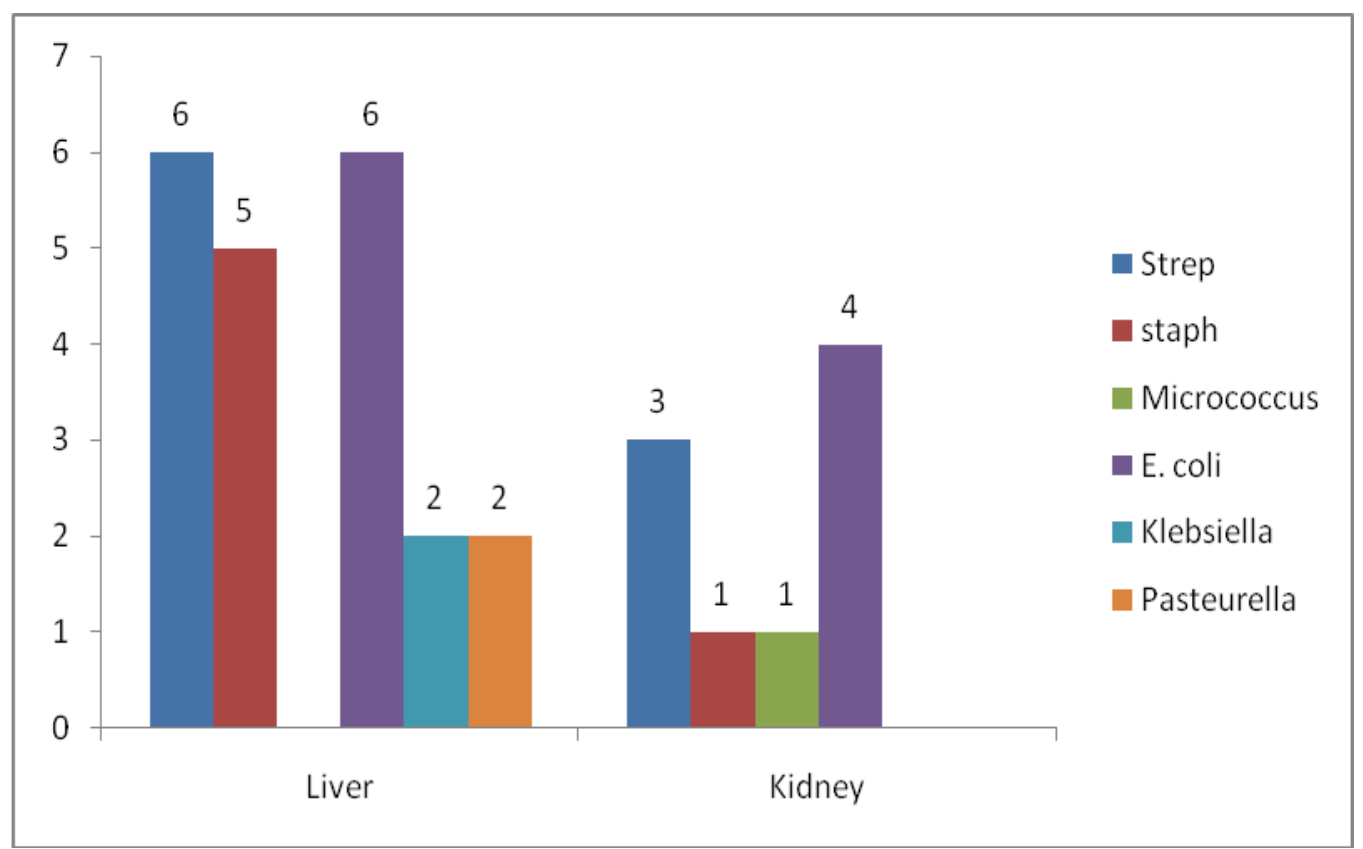

\section{FIG.1: GRAPHICAL REPRESENTATION SHOWING NUMBER OF BACTERIAL ISOLATES FROM LIVER AND KIDNEYS}

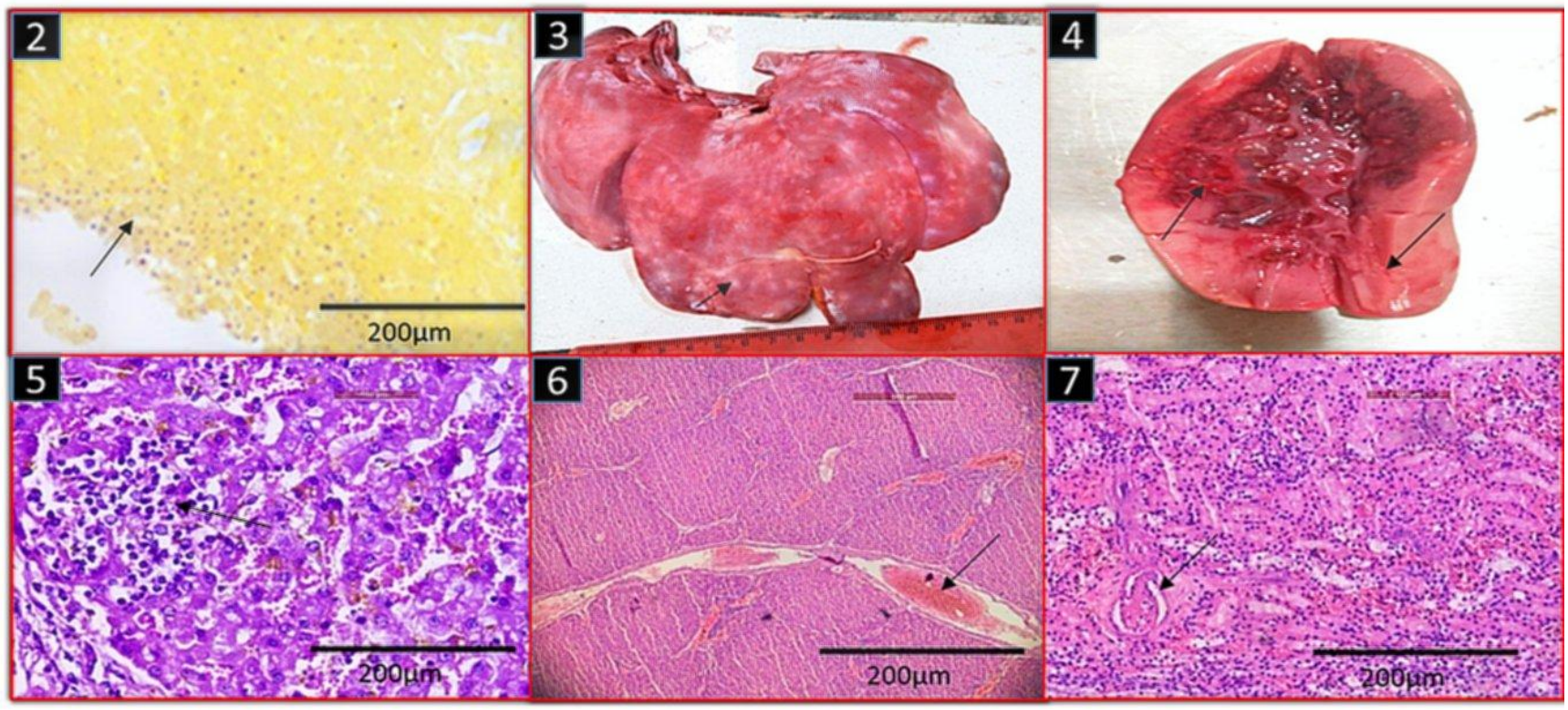

Fig. 2: Brown and Brenn stained section of the liver showing gram positive cocci, X200 Fig.3: Liver showing foci of necrosis, Fig.4: Kidney showing massive haemorrhge in the medullary area and necrosis in the cortical area, Fig.5: Section of the liver showing focal leukocytic infiltration X200, Fig.6: Section of the liver showing congestion of blood vessels X200, Fig.7: Kidney section showing haemorrhage, congestion, interstitial nephritis and glomerulonephritis X200 
Out of the total 14 cases of bacterial infection, mixed bacterial infection were recorded in four cases these were further classified on the basis of the bacteria present below.

Mixed bacterial infection of E. coli, Staphylococcus spp., Micrococcus spp. was detected in a case. Grossly, a large diffused type, grayish white necrotic foci was observed throughout the cortex and medullary regions of the kidney. There were areas of massive haemorrhages in the medullary regions of the kidney (Fig. 4).

Mixed bacterial infection of Streptococcus spp., Staphylococcus spp., E.coli were recorded in three cases. Grossly, Liver showed greyish white focal areas of necrosis throughout the hepatic parenchyma (Fig. 3).

\section{Histopathology}

Microscopically, the liver affected with Streptococcus spp. showed focal leukocytic infiltration which was predominated by polymorphonuclear leukocytes. There was centrilobular necrosis along with haemorrhages with mild type of fatty changes of the hepatocytes. Renal tubules had showed severe coagulative necrosis. There was mild infiltration of polymorphonuclear leukocytes in the interstitial spaces indicating acute type of interstitial nephritis.

A focal leukocytic infiltration predominating with neutrophils were observed (Fig. 5) in liver affected with Staphyllococus aureus.

There was deposition of fibrionous exudates and heavy infiltration of neutrophils in the glisson's capsule. Severe polymorphobuclear leukocytic infiltration along with the deposition of fibrinous exudates over the pericardium of the heart leading to fibrinous pericarditis. Infiltration of large number of polymorphs along with the deposition of fibrinous exudates over the pleura were also revealed in the case of systemic colibacilosis.

The hepatic blood vessels were highly dilated and congested (Fig. 6) in Klebseal septicaemia.

The renal blood vessels were highly dilated and congested. Renal tubules had undergone severe coagulative necrosis and some of the epithelial cells were desquamated into the lumen. There was massive haemorrhages and severe polymorphonuclear leukocytic infiltration in the interstitial spaces. Most of the glomeruli exhibited atrophy of glomerulur tufts and a few scelerosis. (Fig. 7) in mixed infection of E.coli, Staphylococcus spp. and Micrococcus spp.

In mixed infection of Streptococcus spp., Staphylococcus spp. and E.coli the liver showed mild haemorrhages and congestion. Foci of leukocytic infiltration with polymorphonucler leukocytes and monocytes were revealed.

Three cases of Streptococcal infection were recorded in the present study. Grossly, liver showed hepatomegaly, marked congestion, haemorrhgaes, grayish white necrotic foci both focal and diffuse were observed. Kidney showed grayish white necrotic foci and congested blood vessels. Microscopically, variable changes were observed. Liver showed dilation and congestion ranging from mild to severe grade. Haemorrhages at different places of the parenchyma were also noticed. There was focal leukocytic infiltration of polymorphonuclear leukocytes and monocytes. Renal tubules showed severe coagulative necrosis. There was mild infiltration of polymorphonuclear leukocytes in the interstitial spaces indicating acute type of interstitial nephritis. Similar kind of changes were also reported by previous workers. $^{2}$ 
Two cases of Staphylococcal infection were detected in the present study. Grossly, micro abscesses were detected in the liver. Microscopically, abscess consists of focal leukocytic infiltration predominating with neutrophils. These changes were in conformity with the previous report. ${ }^{3}$

Three cases of E.coli infection were recorded during the present study. Grossly, the entire viscera of carcasses showed voluminous fibrinous exudates in the pleural, pericardial and peritoneal cavities. The liver, lung, heart and spleen were covered with fibrinous exudates. Microscopically, heavy leukocytic infiltration including polymorphs along with fibrinous exudates were deposited in serous membranes of visceral organs. Lungs revelaed firbrinous bronchopneumonia. E. coli infection is very common among young domestic animals. Fibrinous polyserositis is a rare case of $E$. coli organism as it is generally caused by Haemophilussuis. The adhesions of the visceral organs due to voluminous fibrins were in concomitant with the previous findings 5 . This present case report on fibrinous polysereositis is of rare findings in pigs of this region and which might be confusing with Glasser's disease. Therefore, such lesions should be studied carefully and will help to treat the animals in proper treatment. There are similarities between the lesions caused by Haemophilussuis and Mycoplasma hyorhinis ${ }^{4}$. The present findings regarding $E$. coli infection also concomitant with the above two diseases. There will be confusion among these lesions and the investigation has to be carried out. Klebsiella septicaemia was recorded in two cases. Grossly, there was marked congestion of the liver. Microscopically, hepatic blood vessels were highly dilated and congested. Similar kind of septicaemic outbreaks were also recorded by previous worker ${ }^{6}$ in preweaned pigs with marked congestion and dilatation of blood vessels in the liver.

\section{References}

1. Vegad, J.L. A textbook of Veterinary General Pathology. $2^{\text {nd }}$ Edn., International Book Distributing Co., U.P. India.

2. Vasconcelos et al., 1994. Lesions caused by natural infection with Streptococcus suistype 9 in weaned pigs. J. Vet. Diagn. Invest. 6, 335-341.

3. Nielsen et al., 2009. A Pig model of acute Staphylococcus aureus induced Pyemia. Acta Veterinaria Scandinavica. 51, 14-19.

4. Neil et al., 1969.Glasser's Disease of Swine Produced by the Intracheal Inoculation of Haemophilussuis. Can. J. comp. Med.33, 188-192.

5. King, S.J. 1968. Porcine polyserositis and arthritis with particular reference to mycoplasmosis and Glasser's disease. Aust. Vet. J.44, 227-230.

6. Bidewell et al., 2018. Emergence of Klebsiella pneumoniae subspecies pneumoniae as a cause of septicaemia in pigs in England. PloSONE. 13(2): e0191958.

7. Brown, J.H. and Brenn, L. 1931. Manual of Histologic Staining Methods of the Armed Forces Institute of

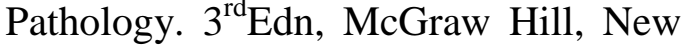
York.

8. Culling C.F.A.1981. Handbook of Histopathological and Histochemical Techniques. $3^{\text {rd }}$ Edn., Pp.319-347.

9. Jones et al., 2006.Veterinary Pathology. $6^{\text {th }}$ Edn., Blackwell Publishing, Oxford, U.K.

10. Jubb et al., 2007. Pathology of Domestic animals. $5^{\text {th }}$ Edn., Elseiver Publication, London.

11. Kidneys relationship with liver. (http://www.shen ong.com/eng/principles/affectliver.html)

12. Luna, L.G. 1968. Manual of Histologic Staining Methods of the Armed Forces 
Institute of Pathology. $3^{\text {rd }}$ Edn, McGraw Hill, New York.

13. Straw et al., 2013. Diseases of Swine. $9^{\text {th }}$ Edn., Blackwell Publishing, Oxford, U.K.

14. Wilcock, B.P. 1979. Experimental Klebsiella and Salmonella Infection in Neonatal Swine. Can. J. Med. 43, 200206.

15. Wolf et al., 2012. Staphylococcus aureus (MSSA) and MRSA (CC398) isolated from post-mortem samples from pigs. Veterinary Microbiology. 158(1): 136-141.

16. Cruickshank R. 1969. Medical Microbiology: a guide to laboratory diagnosis and control of infection. ELBS and E \& S. Livingstone Ltd., Great Britain.

17. Edwards, P. R. and Ewing, W. H. 1972. Identification of enterobacteriaceae. Burgess Publishing Company, Minnesota, USA.

\section{How to cite this article:}

Baruah, B., S.M. Tamuli and Gogoi, S.M. 2019. Pathology of Bacterial Infection in the Liver and Kidneys of Swine. Int.J.Curr.Microbiol.App.Sci. 8(08): 2094-2101.

doi: https://doi.org/10.20546/ijcmas.2019.808.245 